\section{Teaching the teachers}

SIR - Mary Jane Drummond (Nature $352,369 ; 1991)$ refers to the questionable scientific rigour of the "floating and sinking" test for seven-year olds, but there are even more fundamental problems in the teaching of science in primary schools through the new British national curriculum. The most basic is that the whole child population from the age of 5 to 11 is to be taught science by some 200,000 teachers, few of whom have themselves had any education in the subject. The primary teacher therefore needs deeper understanding of the basis of science than those who teach older children.

It is hard to see how teachers who do not themselves understand a concept, or who do not know how a conceptual hierarchy is built up, can possibly inspire children to develop such an understanding. This is especially so when a concept is counter-intuitive. We expect children to understand something about forces, to know that a push or a pull is needed to change the motion of anything. That

\section{Shroud of Turin}

SIR - Pierre Busson laments the various problems arising from the radiocarbon dating of the Shroud of Turin (Nature 352, 187; 1991). As I see it, there is only one problem: the dating itself. The Shroud of Turin is a religious object and, as such, it should never have been subjected to scientific scrutiny.

When Bill Libby developed the radiocarbon dating method, he had a steadfast rule: never to accept for dating anything related to religion. Radiocarbon dating has now shown that the Shroud was woven in the fourteenth century. So what? Scientists will say that that proves that the Shroud is a fake. Believers will say that it is an even greater miracle - the wrapping of the body of Christ in a shroud that was woven 1,300 years later.

Religion is perfect and unchangeable, the work of God. Science is imperfect, everchanging, and, I suspect, the work of the Devil. The two should never be mixed. The scientists who participated in the dating of the Shroud of Turin should repent and promise never to do anything like that again. Creationists are even more guilty, for they have been mixing science and religion for years and years. They should abandon their evil practices forthwith, lest the wrath of God descend upon them like a ton of bricks.

CESARE EMILIANI Department of Geological Sciences, University of Miami,

Coral Gables, Florida 33124, USA seems simple enough and to tie in with experience. But, the argument continues, if there is no push or pull, the motion is unchanged and the object goes on for ever. This is counter-intuitive. Everyone knows that just to keep a broken-down car moving steadily requires a hefty push. Stop pushing and the car stops. And in a way the intuitive approach is the correct one, for it is virtually impossible to escape from forces, and Newton's law is a hypothetical one. The likelihood that teachers who do not understand physics will innocently mislead or confuse their pupils and perhaps block the subsequent development of more advanced concepts must be considerable.

Could this be why Britain is a nation of non-scientists? Why so many people find science daunting and difficult? And if that should be the case, might we do better to leave primary schoolchildren without a science curriculum until such time as the teachers can be taught? Or should we put alongside the primary class teacher a specialist science teacher, trained to meet the challenge of introducing science to young children?

TOM MARGERISON

British Nuclear Forum, (Head of Education)

22 Buckingham Gate,

London SW1E 6LB, UK

\section{Genome ethics}

SIR - John Maddox's update on the Human Genome Project (Nature 352, $11-14$; 1991) deals fleetingly with the ethical problems posed by this research. The author mentions the concern that individuals endowed with wrong genes may be subjected to insurance discrimination, and tends to play down German sensitivity regarding eugenics, believing such applications unlikely. However, there are reasons for concern.

After the visually discernible chromosomal irregularities are investigated, the genetic cartographers will tackle the genes that define our anatomical and physiological features, because these, given our long biological history, very probably represent the bulk of our genetic makeup.

Inevitably, the investigators will chance upon those genes that have originated late in our development and which define the anatomical and physiological substrates of human cognition. Our very consciousness may be found to be gene-dependent. This will have serious consequences.

Our manipulation of the genetic constitution of animals and plants for economic reasons is quite extensive, even though our knowledge of thei, genome is limited.

Is there any doubt, once it becomes clear what underlies human intelligence and memory, that this knowledge will be put to use in the name of individual and national interest? Can we afford not to engage in eugenics? Human-directed evolution is inevitable and as it is faster than natural evolution it will be within its power to change our race within a few generations.

Who will have access to this knowledge and when, how and to what end? As most if not all of the funding of the project is public, the public should determine these matters.

EMIL ASCHHEIM

12716 Headwater Circle,

West Palm Beach, Florida 33414, USA

\section{Wittgenstein}

SIR - J. R. Smythies has tried ${ }^{1}$ to resolve the long discussion of Wittgenstein's merits by diagnosing him as insane. In particular, he mentions paranoia, schizoid personality disorder and schizophrenia and also cites some reported life events and the "schizophrenese" speech disorder, for which neither a scientific definition nor a citation is given. We cannot agree with these psychiatric statements.

(1) The diagnosis of schizophrenia, and, even more, that of schizoid personality disorder, is a very difficult and uncertain procedure even in the assessment of living patients. But the diagnosis does not rely on a patient's 'schizophrenese' writing ${ }^{2}$. Moreover, Wittgenstein's life argues against a diagnosis of schizophrenia. In retrospect, a diagnosis of cyclothymia seems much more likely. Also the family history and experiences of living relatives of Wittgenstein, which cannot be discussed in detail for ethical reasons, argue against schizophrenia.

(2) The description of 'schizophrenese' writing applies not only to Wittgenstein's work, but to that of many other philosophers and theologians $s^{3,4}$.

(3) Even a diagnosis of psychiatric illness does not of itself diminish the content of the thoughts and ideas of particular patients. Psychiatry should try to get the better of the common prejudice against insanity.

P. FISCHER

B. KÜFFERLE

P. BERNER

Psychiatrische Universitätsklinik,

Universität Wien,

A-1090 Wien, Austria

1. Smythies, J. R. Nature 350, 9 (1991).

2. Diagnostic and Statistical Manual of Mental Disorders, American Psychiatric Association 2nd edn (Washington, DC, 1987)

3. Rochester, S. R. \& Martin, J. R. Crazy Talk: A Study of the Discourse of Schizophrenic Speakers. (Plenum, New York, 1979).

4. Schwartz, S. Behavioural and Brain Sciences 5, 579626 (1982). 